\title{
THE INFLUENCE OF THE WATER SUPPLY ON THE BIOACTIVE COMPOUNDS OF DIFFERENT TOMATO VARIETIES
}

\author{
M. BERKI ${ }^{\mathrm{a} *}$, H.G. DAOOD ${ }^{\mathrm{b}}$ and L. HeLYes ${ }^{\mathrm{b}}$ \\ ${ }^{a}$ National Agricultural Research and Innovation Center, Food Research Institute \\ H-1022 Budapest, Herman Ottó u.15, Hungary \\ ${ }^{\mathrm{b}}$ Horticultural Institute, Faculty of Agricultural and Environmental Sciences, Szent István University, \\ H-2301 Gödöllő, Páter K. u.1. Hungary
}

(Received: 10 April 2014; accepted: 29 July 2014)

\begin{abstract}
The objective of this study was to investigate the influence of irrigation on the composition and content of phenolic compounds and carotenoids in different tomato cultivars using HPLC/DAD-UV technique and reverse-phase (RP) chromatographic columns for analysis. Among phenols, the quercetin derivatives and hydroxycinnamic acids and their derivatives were the major compounds, while lycopene was the dominant carotenoid in the extract of tomato. It was found that the response of tomatos to shortage of water is affected by genetic factors and seasonal environmental variations. In general, $100 \%$ irrigation yielded tomatoes with the lowest level of carotenoids and polyphenols. In 2012, when the temperature and number of sunny hours were at record levels, the non-irrigated plants of cultivar Strombolino yielded tomatoes with significantly higher levels of carotenoids and phenols than that of the other cultivars.
\end{abstract}

Keywords: phenolics, carotenoids, HPLC, tomato, irrigation

The tomato is one of most important vegetables worldwide. Its consumption either as fresh fruit or as processed product is higher than for all other fruit and vegetables. The tomato has been reported to be an important source of bioactive compounds such as carotenoids, tocopherols and phenolic compounds in the human diet (ABUSHITA et al., 2000; STEWART et al., 2000; Slimestad \& Verheul, 2009).

Among carotenoids, tomatoes contain high levels of biologically active lycopene and, in some cultivars, considerable amounts of $\beta$-carotene (Котікоva et al., 2011). Over the last decades, epidemiological studies have shown a strong correlation between a high dietary intake of biologically active carotenoids and a reduced risk of various serious cancers and cardiovascular disease (CLINTON, 1998; Johnson, 2000; KrinsKy \& JoHnson, 2005; STACEWICZSAPUNTZAKIS \& BOWEN, 2005; LARSSON et al., 2010).

The phenols are a group of secondary plant metabolites, which play key roles in plant protection, including defense against pathogens and protection against UV-B radiation, and contain several chemical structures, from simple molecules to highly polymerized forms. Polyphenols are highly reactive antioxidants reducing the risk of several chronic diseases (ANDERSEN \& MARKHAM, 2006).

In studies by RafFo and co-workers (2006), Slimestad and Verheul (2009), GómezRomero and co-workers (2010), and SÁNChez-Rodríguez and co-workers (2012) the main phenolic acids in tomatoes were identified as hydroxycinnamic acids (caffeic, chlorogenic, ferulic acid) and their derivatives, the main polyphenols were rutin and naringenin in addition

\footnotetext{
* To whom correspondence should be addressed.

Phone: +36-1-796-0400; fax: +36-1-796-0449; email: m.berki@cfri.hu
} 
to some minor polyphenols, such as kaempferol, quercetin, naringenin derivatives. Over the last decade the phenolic compounds in tomato have been investigated with respect to differences between tomato cultivars, effects of seasonal variations, fertilisers, storage times, water stress, etc. (STEWART et al., 2001; DumAs et al., 2003).

Environmental factors and agricultural techniques used in cultivation have been found to have an impact on the content of antioxidant compounds in tomatoes (DumAs et al., 2003). SÁnchEZ-RodRíGuEZ and co-workers (2011) examined responses of leaves of cherry tomato cultivars to water stress and their data showed that the quantity of phenolic compounds of cv. Zarina rose due to the effect of moderate water stress.

During the last decades there were dramatic environmental changes, including water deficiency, salinity, and warming. Our main objective in the present work was to study the effect of water stress on the main bioactive compounds in tomato fruit from different cultivars.

\section{Materials and methods}

\subsection{Plant material and treatments}

Three tomato cultivars - Strombolino, Triple Red, and Uno Rosso - were grown in the Experimental Farm of the Institute of Horticulture, Szent István University, Gödöllö, Hungary. They utilized different water supply quantities $(50 \%, 75 \%, 100 \%$ irrigated with the control being non-irrigated) during the 2010, 2011, and 2012 vegetable growing seasons. Drip irrigation water was dispensed according to the air temperature. Each cultivar was cultivated in four replications. The tomato fruits were collected at fully mature stage with average "berry" size for each cultivar and immediatelly transported to the laboratory. The whole tomato batch was homogenized using Waring blender and the samples were stored at $-20{ }^{\circ} \mathrm{C}$ until analysis.

\subsection{Chemicals}

All analytical grade exrtaction solvents (methanol, acetic acid, 1,2-dichloroethane, ethanol), and HPLC grade solvents (acetonitrile, formic acid, acetone) were purchased from VWR International Kft. (Debrecen, Hungary). The analytical standards (chlorogenic, caffeic, ferulic, gallic acid, catechin, naringin, rutin, $\beta$-carotene, lycopene) were purchased from Sigma-Aldrich Ltd. (Budapest, Hungary). Quartz sand and $\mathrm{Na}_{2} \mathrm{SO}_{4}$ were obtained from Reanal Ltd. (Budapest, Hungary).

\subsection{Extraction and determination of phenolics components}

Phenolic components were extracted from $10.0 \mathrm{~g}$ well-homogenized samples with $25 \mathrm{ml}$ of solution consisting of 25:75:2 water-methanol-acetic acid. After mechanical shaking for 20 min, the mixture was left at $+4{ }^{\circ} \mathrm{C}$ overnight. The samples were again shaken for $10 \mathrm{~min}$ and then filtered through filter paper. The residues were re-extracted twice with $2.5 \mathrm{ml}$ solvent. The filtrates were further cleaned by passing through a $0.45-\mathrm{mm}$ HPLC syringe filter before injection into HPLC column for chromatographic determination.

Chromatographic separation of phenols was performed on an EC Nucleodur Sphinx RP, $3 \mu \mathrm{m}, 150 \times 4.6 \mathrm{~mm}$ analytical column, using gradient elution. The mobile phase was (A) $1 \%$ formic acid in water and (B) acetonitrile. The gradient elution started with a linear gradient from $98.5 \% \mathrm{~A} / 1.5 \% \mathrm{~B}$ to $75 \% \mathrm{~A} / 25 \% \mathrm{~B}$ in $28 \mathrm{~min}$; isocratic elution $75 \% \mathrm{~A} / 25 \% \mathrm{~B}$ for $4 \mathrm{~min}$; 
gradient elution from $75 \% \mathrm{~A} / 25 \% \mathrm{~B}$ to $50 \% \mathrm{~A} / 50 \% \mathrm{~B}$ in $8 \mathrm{~min}$; isocratic elution $50 \% \mathrm{~A} / 50 \%$ $\mathrm{B}$ for $3 \mathrm{~min}$; and gradient elution from $50 \% \mathrm{~A} / 50 \% \mathrm{~B}$ to $98.5 \% \mathrm{~A} / 1.5 \% \mathrm{~B}$ in $3 \mathrm{~min}$. The

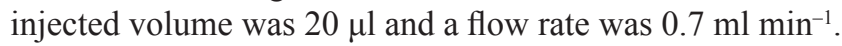

Peaks of phenol components were identified by comparing their spectral characteristics and retention times with those of available standards. Integration was done at the maximum absorption of each compound. Phenols having absorption maxima around $280 \mathrm{~nm}$ were quantified as gallic acid-equivalent, while those having absorbance maxima around $320 \mathrm{~nm}$ or $355 \mathrm{~nm}$ were quantified as rutin-equivalent.

\subsection{Extraction and determination of carotenoid components}

Three grams of tomato was extracted after crushing in a crucible mortar in the presence of quartz sand, with $20 \mathrm{ml}$ methanol. The mixture was then shaken with a mixture of $10 \mathrm{ml}$ methanol and $50 \mathrm{ml} \mathrm{1,2-dichloroethane} \mathrm{for} 10 \mathrm{~min}$. Bi-distilled water was added to separate the polar and non-polar phases (DAOOD et al., 1987). The pigment-containing solvent was dehydrated over anhydrous $\mathrm{Na}_{2} \mathrm{SO}_{4}$ and evaporated at $40{ }^{\circ} \mathrm{C}$ to dryness under vacuum. The residues were re-dissolved in $5 \mathrm{ml}$ HPLC grade acetone. After further clean up by passing through a PTFE $0.45 \mu \mathrm{m}$ syringe filter, the clear solution was injected into the HPLC column.

Separation of carotenoids was performed on cross-linked base-deactivated reversedphase EC 150/4.6 Nucleodur C18 ISIS $3 \mu \mathrm{m}$ column with gradient elution of water in acetone (DAOOD et al., 2013). Peak identification was based on comparison of retention times and spectral characteristics with those of pure standards and tentatively on the basis of comparison with literature data.

\subsection{HPLC instrument}

A Waters Alliance system consisting of a Model 2695 separation module and a Model 2996 photodiode-array detector was used for the chromatographic analysis of the tomato phenols and carotenoids. The system was operated by Empower software.

\subsection{Statistical analysis}

Significance of the results and statistical differences were analysed using Microsoft Office Excel. The effect of irrigation was analysed by performing two samples two tailed Students' $t$-test. The quantity of identified compounds of non-irrigated samples (control) was compared to samples with different water supplies every year.

Values represent the mean and standard deviation $( \pm$ ) of four replicates per cultivar and expressed as $\mathrm{mg} / 100 \mathrm{~g}$ of dry weight (DW).

\section{Results and discussion}

\subsection{Effect on phenols}

With respect to phenols occuring in tomatoes, ten compunds could be detected, identified according to their UV spectral analysis and retention behaviour, and quantitatively determined in the different samples. These compounds are: quercetin-glucoside, rutin, caffeic acid and its derivatives, neochlorogenic, chlorogenic, ferulic, gallic acid, catechin, and naringin. The level of phenolics from tomato cultivars showed substantial variations. For example, in every 
season the cherry type tomato Strombolino contained 1.5-2 times higher amounts of polyphenols than conventional types. It is to be mentioned that naringin $(0.5 \pm 0.08-22.4 \pm 2.35$ $\mathrm{mg} / 100 \mathrm{~g} \mathrm{DW}$ ) was detected only in cherry tomatoes. In 2012 concentrations of total polyphenols in the Triple Red type tomato were significantly higher than in Uno Rosso, which is one of the conventional types, as well.

The results of the HPLC analyses of Strombolino cultivar are shown in Table 1. The main phenolic acids were identified as chlorogenic $(23.0 \pm 3.05-89.7 \pm 11.93 \mathrm{mg} / 100 \mathrm{~g} \mathrm{DW})$ and caffeic acid $(13.4 \pm 3.10-28.9 \pm 3.81 \mathrm{mg} / 100 \mathrm{~g} \mathrm{DW})$. Rutin was the major polyphenolic compound and ranged between $33.2 \pm 5.65$ and $132.6 \pm 18.05 \mathrm{mg} / 100 \mathrm{~g} \mathrm{DW}$.

The content of both groups of phenols in tomato of Strombolino cultivar was not affected by irrigation during the seasons 2010 and 2011, while significant difference was found between the fruit of irrigated and non-irrigated plants in 2012, when the season temperature and number of sunny hours were extremely high. High temperature stress on the shikimate pathway, where most of the secondary metabolites are synthesized, increases activity of phenylalanine-ammonia-lyase (PAL), which induces accumulation of soluble phenolic compounds (RIVERo et al., 2001) .

Table 1. Changes in concentrations of phenolic compounds as an effect of irrigation in Strombolino cultivar (2010-2012)

\begin{tabular}{|c|c|c|c|c|c|c|}
\hline \multirow[t]{2}{*}{ Comp. } & \multicolumn{2}{|c|}{2010} & \multicolumn{2}{|c|}{2011} & \multicolumn{2}{|c|}{2012} \\
\hline & Non-irrigated & Irrigated & Non-irrigated & Irrigated & Non-irrigated & Irrigated \\
\hline Q-glu & $16.4 \pm 1.28$ & $19.9 \pm 3.26^{\mathrm{b}}$ & $18.5 \pm 3.53$ & $17.6 \pm 1.58$ & $26.9 \pm 1.90$ & $12.5 \pm 1.49^{\mathrm{a}}$ \\
\hline Rutin & $76.4 \pm 9.86$ & $68.2 \pm 14.95$ & $100.7 \pm 16.78$ & $87.5 \pm 12.55$ & $132.6 \pm 18.05$ & $33.2 \pm 15.65^{\mathrm{a}}$ \\
\hline N-chlo & $21.3 \pm 1.15$ & $17.4 \pm 2.02^{\mathrm{a}}$ & $29.4 \pm 4.40$ & $20.0 \pm 1.85^{\mathrm{a}}$ & $23.6 \pm 1.39$ & $8.8 \pm 3.56^{\mathrm{a}}$ \\
\hline Chlo & $42.3 \pm 2.11$ & $38.9 \pm 4.74$ & $23.0 \pm 3.05$ & $35.8 \pm 13.63^{b}$ & $89.7 \pm 11.93$ & $58.7 \pm 10.83^{\mathrm{a}}$ \\
\hline Caf & $27.1 \pm 1.53$ & $28.9 \pm 3.81$ & $13.4 \pm 3.10$ & $14.3 \pm 1.84$ & $20.5 \pm 2.60$ & $19.3 \pm 16.16^{b}$ \\
\hline Nar & $19.7 \pm 2.22$ & $22.4 \pm 2.35$ & $0.5 \pm 0.17$ & $0.5 \pm 0.08$ & $1.7 \pm 0.43$ & $0.7 \pm 0.07^{\mathrm{a}}$ \\
\hline T pp & $125.3 \pm 9.74$ & $119.4 \pm 21.5$ & $122.4 \pm 20.4$ & $108.3 \pm 14.3$ & $165.7 \pm 20.3$ & $58.8 \pm 4.55^{\mathrm{a}}$ \\
\hline Т pa & $102.3 \pm 2.53$ & $96.5 \pm 10.1$ & $114.1 \pm 11.2$ & $119.3 \pm 18.6$ & $167.2 \pm 8.4$ & $109.4 \pm 12.02^{\mathrm{a}}$ \\
\hline
\end{tabular}

Q-glu: quercetin-glucoside; N-chlo: neochlorogenic acid; Chlo: chlorogenic acid; Caf: caffeic acid; Nar: naringenin; $\mathrm{T}$ pp: total polyphenols; $\mathrm{T}$ pa: total phenolic acids

Means and standard deviation $( \pm$ ) of four replicates per cultivar expressed as $\mathrm{mg} / 100 \mathrm{~g}$ of dry weight (DW)

Means followed by letters significantly different $\mathrm{a}: \mathrm{P} \leq 0.005$; $\mathrm{b}: \mathrm{P} \leq 0.05$

The highest concentration of phenols was also measured in fruit of non-irrigated plants from other cultivars grown during two seasons. Uno Rosso cultivar contained significantly higher concentrations of phenolic compounds in 2012 than in 2011. Furthermore, there was no significant difference between $50 \%$ and $75 \%$ irrigation in their effect on the content of the phenolic compounds in tomato fruit. GómEz-ROMERo and co-workers (2010) carried out metabolite profiling of three different tomato cultivars and measured amounts of $4.35 \pm 0.23$ $-16.37 \pm 0.32 \mathrm{mg} / 100 \mathrm{~g}$ DW for caffeic acid and $6.18 \pm 0.01-9.25 \pm 0.10 \mathrm{mg} / 100 \mathrm{~g} \mathrm{DW}$ for rutin. 
Table 2. Changes in concentrations of phenolic compounds as a function of different water supplies in Uno Rosso cultivar (2011 and 2012)

\begin{tabular}{lcccc}
\hline Compounds & \multicolumn{3}{c}{ Uno Rosso cultivar 2011 } \\
\cline { 2 - 4 } & Non-irrigated & $50 \%$ Irrigated & $75 \%$ Irrigated & $100^{\%}$ Irrigated \\
\hline Quercetin-glucoside & $16.5 \pm 4.33$ & $9.1 \pm 0.90^{\mathrm{a}}$ & $11.0 \pm 0.50^{\mathrm{b}}$ & $11.5 \pm 2.63^{\mathrm{a}}$ \\
Rutin & $24.1 \pm 3.06$ & $19.0 \pm 2.11^{\mathrm{b}}$ & $20.9 \pm 2.06$ & $17.2 \pm 1.73^{\mathrm{a}}$ \\
Neochlorogenic acid & $11.6 \pm 1.37$ & $10.2 \pm 0.80^{\mathrm{b}}$ & $9.3 \pm 1.20^{\mathrm{b}}$ & $7.0 \pm 0.86^{\mathrm{a}}$ \\
Chlorogenic acid & $9.4 \pm 1.28$ & $8.9 \pm 1.36$ & $20.6 \pm 3.37^{\mathrm{a}}$ & $16.0 \pm 2.22^{\mathrm{a}}$ \\
Caffeic acid & $7.8 \pm 1.05$ & $6.7 \pm 0.74^{\mathrm{b}}$ & $7.6 \pm 1.62$ & $7.3 \pm 1.11^{\mathrm{a}}$ \\
Total polyphenols & $47.8 \pm 7.58$ & $32.5 \pm 2.82^{\mathrm{a}}$ & $35.7 \pm 2.53^{\mathrm{b}}$ & $33.3 \pm 3.45^{\mathrm{a}}$ \\
Total phenolic acids & $53.5 \pm 1.80$ & $45.0 \pm 2.61^{\mathrm{a}}$ & $56.4 \pm 1.97^{\mathrm{b}}$ & $46.4 \pm 3.33^{\mathrm{a}}$ \\
\hline Compounds & & Uno Rosso cultivar 2012 & $75 \%$ Irrigated & $100^{\mathrm{I}}$ Irrigated \\
\cline { 2 - 5 } & Non-irrigated & $50 \%$ Irrigated & $11.0 \pm 1.81$ & $9.3 \pm 1.37^{\mathrm{a}}$ \\
\hline Quercetin-glucoside & $14.3 \pm 2.29$ & $15.7 \pm 1.95$ & $28.7 \pm 4.63^{\mathrm{b}}$ & $22.4 \pm 3.41^{\mathrm{a}}$ \\
Rutin & $63.1 \pm 8.55$ & $36.1 \pm 4.47^{\mathrm{a}}$ & $13.4 \pm 1.15^{\mathrm{a}}$ & $6.8 \pm 0.74^{\mathrm{a}}$ \\
Neochlorogenic acid & $22.4 \pm 1.20$ & $14.7 \pm 2.42^{\mathrm{a}}$ & $24.6 \pm 4.77$ & $37.4 \pm 6.02^{\mathrm{a}}$ \\
Chlorogenic acid & $28.1 \pm 4.70$ & $32.4 \pm 5.83$ & $9.7 \pm 1.61^{\mathrm{b}}$ & $10.9 \pm 0.92$ \\
Caffeic acid & $11.5 \pm 1.27$ & $8.7 \pm 1.18^{\mathrm{a}}$ & $42.4 \pm 4.86^{\mathrm{b}}$ & $34.2 \pm 2.79^{\mathrm{a}}$ \\
Total polyphenols & $82.5 \pm 10.77$ & $55.4 \pm 6.63^{\mathrm{a}}$ & $60.2 \pm 6.41^{\mathrm{a}}$ & $65.9 \pm 4.22^{\mathrm{a}}$ \\
Total phenolic acids & $74.0 \pm 6.88$ & $65.2 \pm 9.35^{\mathrm{a}}$ & &
\end{tabular}

Means and standard deviation ( \pm ) of four replicates per cultivar expressed as $\mathrm{mg} / 100 \mathrm{~g}$ of dry weight (DW) Means followed by letters significantly different $\mathrm{a}$ : $\mathrm{P} \leq 0.005$; $\mathrm{b}$ : $\mathrm{P} \leq 0.05$

Compared means of the two normal type tomato cultivars in 2012 showed that the nonirrigated Uno Rosso cultivar contained significantly less phenols than Triple Red (Fig. 1). As an effect of irrigation, the amounts of total polyphenols and total phenolic acids decrased by the same rate in the Triple Red cultivar, but in Uno Rosso the content of polyphenols decreased at a higher rate than of phenolic acids.

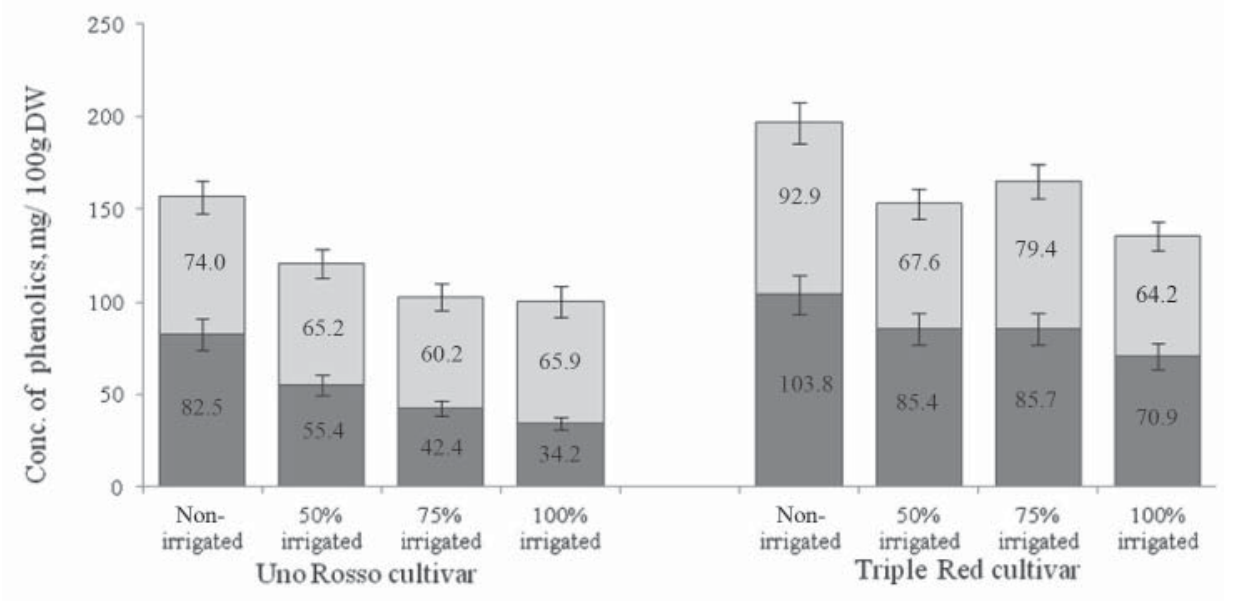

Fig. 1. Changes in concentrations of phenolic compounds as an effect of different water supplies in Uno Rosso and Triple Red cultivars ( 2012). $\square$ : total polyphenols; $\square$ : total phenolic acids 


\subsection{Effect on carotenoids}

In the evaluation we focused on lycopene as being the dominant carotenoid compound and because of its high biological activity. The highest level and proportion of lycopene were found in Strombolino cultivar, making it of special interest from the nutritional and tomato processing points of view (Table 3 ). Like that of phenols, biosynthesis of carotenoids was activated in Strombolino in 2012 as an effect of high temperature and number of sunny hours in the season. Seasonal variations have been reported to affect significantly the level of quality and nutritional components in horticultural crops (HowARD et al., 2003; BAE et al. 2014).

Table 3. Changes in concentrations of carotenoids compounds as an effect of different water supply in Strombolino cultivar (2010-2012)

\begin{tabular}{|c|c|c|c|c|c|c|}
\hline \multirow[t]{2}{*}{ Comp. } & \multicolumn{2}{|c|}{2010} & \multicolumn{2}{|c|}{2011} & \multicolumn{2}{|c|}{2012} \\
\hline & Non-irrigated & Irrigated & Non-irrigated & Irrigated & Non-irrigated & Irrigated \\
\hline Lyc & $56.3 \pm 5.87$ & $64.7 \pm 6.52$ & $73.4 \pm 25.45$ & $76.6 \pm 26.47$ & $116.0 \pm 2.38$ & $71.4 \pm 9.80^{\mathrm{a}}$ \\
\hline Z-lyc & $4.0 \pm 3.35$ & $6.1 \pm 1.00$ & $19.9 \pm 1.92$ & $18.2 \pm 0.44$ & $19.2 \pm 0.39$ & $16.2 \pm 0.22^{\mathrm{a}}$ \\
\hline$\beta$-car & $4.6 \pm 1.12$ & $4.9 \pm 0.68$ & $3.8 \pm 0.82$ & $4.6 \pm 0.36$ & $4.7 \pm 0.61$ & $4.5 \pm 0.37$ \\
\hline Total & $74.6 \pm 10.98$ & $84.6 \pm 8.27$ & $108.4 \pm 29.84$ & $116.0 \pm 24.01$ & $168.3 \pm 4.96$ & $114.8 \pm 9.83^{\mathrm{a}}$ \\
\hline
\end{tabular}

Lyc: lycopene; Z-lyc: Z-lycopene; $\beta$-car: $\beta$-carotene; Total: Total carotenoids

Means and standard deviation $( \pm$ ) of four replicates per cultivar expressed as $\mathrm{mg} / 100 \mathrm{~g}$ of dry weight (DW)

Means followed by letters significantly different $\mathrm{a}=\mathrm{P} \leq 0.005 ; \mathrm{b}=\mathrm{P} \leq 0.05$

Table 4. Changes in concentrations of carotenoids compounds as an effect of different water supply in Uno Rosso cultivar (2011-2012)

\begin{tabular}{|c|c|c|c|c|}
\hline \multirow[t]{2}{*}{ Component } & \multicolumn{4}{|c|}{ Uno Rosso cultivar 2011} \\
\hline & Non-irrigated & $50 \%$ Irrigated & $75 \%$ Irrigated & $100 \%$ Irrigated \\
\hline Lycopene & $61.7 \pm 8.29$ & $53.1 \pm 4.11$ & $29.7 \pm 6.42^{\mathrm{a}}$ & $57.9 \pm 17.50$ \\
\hline Z-lycopene & $19.1 \pm 1.30$ & $16.1 \pm 0.66^{\mathrm{b}}$ & $10.9 \pm 0.26^{\mathrm{a}}$ & $14.6 \pm 0.86^{\mathrm{a}}$ \\
\hline$\beta$-carotene & $1.4 \pm 0.14$ & $1.6 \pm 0.02$ & $1.1 \pm 0.05^{\mathrm{b}}$ & $1.7 \pm 0.21$ \\
\hline Total carotenoids & $95.5 \pm 10.51$ & $80.0 \pm 5.00^{\mathrm{b}}$ & $57.5 \pm 5.44^{\mathrm{a}}$ & $86.0 \pm 16.28$ \\
\hline Lycopene & $35.4 \pm 1.17$ & $37.3 \pm 4.91$ & $29.8 \pm 5.24^{b}$ & $47.3 \pm 4.08$ \\
\hline Z-lycopene & $9.6 \pm 0.56$ & $8.8 \pm 0.37^{b}$ & $8.5 \pm 0.48^{\mathrm{a}}$ & $7.4 \pm 0.95^{\mathrm{a}}$ \\
\hline$\beta$-carotene & $1.2 \pm 0.15$ & $1.2 \pm 0.08^{\mathrm{a}}$ & $1.0 \pm 0.09^{\mathrm{b}}$ & $1.5 \pm 0.29^{b}$ \\
\hline Total carotenoids & $66.4 \pm 2.41$ & $63.5 \pm 2.79$ & $56.2 \pm 4.71^{\mathrm{a}}$ & $72.7 \pm 2.53$ \\
\hline
\end{tabular}

Means and standard deviation ( \pm ) of four replicates per cultivar expressed as $\mathrm{mg} / 100 \mathrm{~g}$ of dry weight (DW) Means followed by letters significantly different $\mathrm{a}: \mathrm{P} \leq 0.005$; $\mathrm{b}$ : $\mathrm{P} \leq 0.05$ 
The increase in phenol and carotenoid contents may also be linked to the effect of meteorological parameters on dry matter content of tomato. Regarding the effect of irrigation on carotenoid content of tomato, the results of two years indicated that $75 \%$ irrigation resulted in tomatoes with significantly lower lycopene concentration particularly in the Uno Rosso cultivar. Other irrigation levels did not show any significant differences (Table 4). Z-lycopene tended to significantly decrease as a consequence of irrigation, while level of $\beta$-carotene increased with $100 \%$ irrigation. This inverse relation between lycopene and $\beta$-carotene may be due to activation, by high water supply, of cyclase enzyme, which is responsible for cyclation of lycopene to $\beta$-carotene.

Opposite tendency for lycopene was noticed in the growing season of 2012. Lycopene content in tomato fruit from 100\% irrigated Triple Red cultivar (Fig. 2) was significantly higher than that found in fruit from non-irrigated plants.

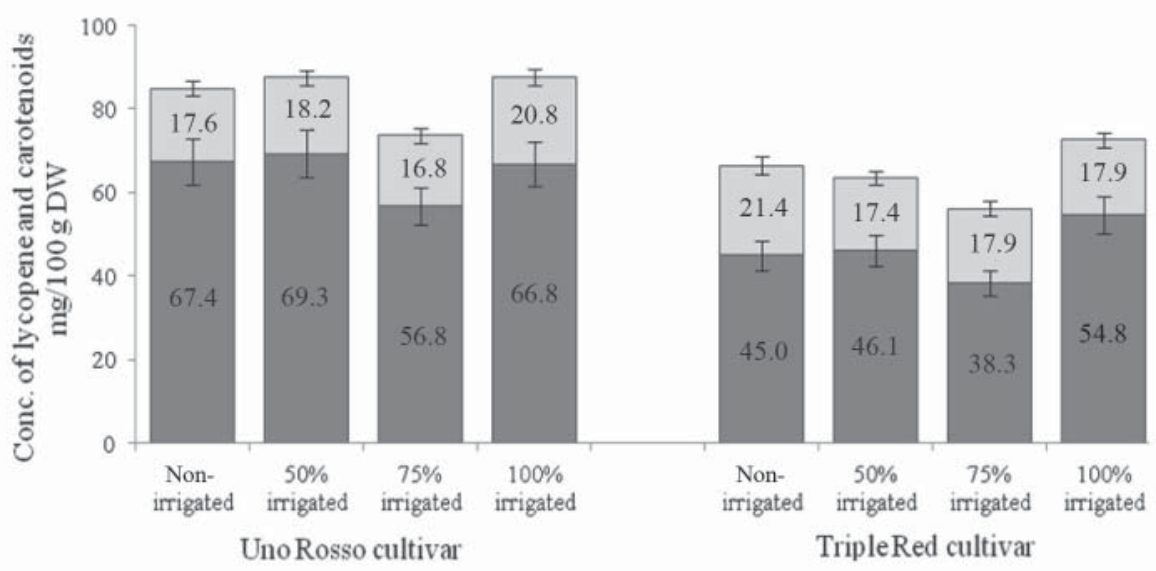

Fig. 2. Changes in concentrations of lycopene and carotenoids as an effect of different water supply in Uno Rosso and Triple Red cultivars (2012). $\square$ : licopene + Z-lycopene; $\square$ : carotenoids

\section{Conclusions}

These results also showed that response of different cultivars to water stress is different. It is therefore important to optimize irrigation to produce tomatoes with high content of bioactive nutrients such as carotenoids, especially lycopene, a compound responsible for the red color and contributing substantially to the biological activity of tomatoes. The genetic, technological, and environmental factors can influence, to a significant extent, the antioxidant content and nutritive value of tomato products.

The authors would like to thank the National Development Agency (NFÜ) for financial support under project grant no. TECH-09-A3- 2009-0230, USOK2009. We thank the Ministry of Human Resources for supporting Research Centre of Excellence - 8526-5/2014/TUDPOL, Szent István University, and KTIA-AIK-12-1-2012-0012 projects. 


\section{References}

Abushita, A., Daood, H.G. \& Biacs, P. (2000): Change in carotenoids and antioxidant vitamins in tomato as an effect of varietal and technological factors. J. Agric. Food Chem., 48, 2075-2081.

Andersen, M. \& Markham, K.R. (2006): Flavonoids: chemistry biochemistry and application. CRC, Boca Raton, FL., 1245 pages.

Bae, H., Jayaprakasha, G., Crosby, K., Yoo, K.S., Leskovar, D.I., Jifon, J. \& Patil, B.S. (2014): Ascorbic acid, capsaicinoid, and flavonoid aglycone concentrations as a function of fruit maturity stage in greenhouse-grown peppers. J. Food Compos. Anal., 33, 195-202.

Clinton, S.K. (1998): Lycopene: chemistry, biology, and implications for human health and disease. Nutr. Rev. 56, $35-51$.

Daood, H.G., Biacs, P., Vinkler, M., Hoschke, A. \& Hajdu, F. (1987): Separation and identification of tomato fruit pigments by TLC and HPLC. Acta Alimentaria, 16, 339-350.

Daood, H.G., Bencze, Gy., Palotás, G., Pék, Z., Sidikov, A. \& Helyes, L. (2013): HPlC analysis of carotenoids from tomatoes using cross-linked C18 column and MS detection. J. Chromatogr. Sci., 139, 1-7.

Dumas, Y., Dadomo, M., Lucca, G. \& Grolier, P. (2003): Effect of environmental factors and agricultural techniques on antioxidant content of tomato. J. Sci. Food Agric., 83, 369-382.

Gómez-Romero, M., Segura-Carratero, A. \& Fernández-Gutiérrez, A. (2010): Metabolite profiling and quantification of phenolic compounds in methanol extract of tomato fruit. Phytochemistry, 71, 1848-1864.

Howard, L.R., Clark, J.R. \& Brownmiller, C. (2003): Antioxidant capacity and phenolic content in blueberries as affected by genotype and growing season. J. Sci. Food Agric., 83, 1238-1247.

Johnson, E.J. (2000): The role of lutein in disease prevention. Nutr. Clin. Care, 3, 289-293.

Kotíkova, Z., Lachman, J., Hejtmánková, A. \& Hejtmánková, K. (2011): Determination of antioxidant activity and content in tomato varieties and evaluation of mutual interaction between antioxidants. LWT-Food Sci. Technol., 44, 1703-1710.

Krinsky, N.I. \& Johnson, E. (2005): Carotenoid action and their relation to health and disease. Mol. Aspects Med., 26, 459-516.

Larsson, S., Bergkvist, L. \& Wolk, A. (2010): Dietary carotenoids and risk of hormone receptor-defined breast cancer in a prospective cohort of Swedish women. Eur. J. Cancer, 46, 1079-1085.

Raffo, A., La Mafla, G., Fogliano, V., Maiani, G. \& Quaglia, G. (2006): Seasonal variations is antioxidant components of cherry tomatoes (Lycopersicon esculentum cv. Naomi F1). J. Food Compos. Anal., 19, 11-19.

Rivero, R.M., Ruiz, J.M., Garcia, P.C., López-Lefebre, L.R., Sánchez, E. \& Romero, L. (2001): Resistance to cold and heat stress: accumulation of phenolic compounds in tomato and watermelon plants. Plant Sci., 160, 315321.

Sánchez-Rodríguez, E., Moreno, D.A., Ferreres, F., Rubio-wilhelmi, M.M. \& Ruiz, J.M. (2011): Differential responses of five cherry tomato varieties to water stress: Changes on phenolic metabolites and related enzymes. Phytochemistry, 72, 723-729.

Sánchez-Rodríguez, E., Ruiz, J.M., Ferreres, F. \& Moreno, D.A. (2012): Phenolic profiles of cherry tomatoes as influenced by hydric stress and rootstock technique. Food Chem., 134, 775-782.

Stacewicz-Sapuntzakis, M. \& Bowen, P.E. (2005): Role of lycopene and tomato products in prostate health. Biochim. Biophys. Acta, 1740, 202-205.

Slimestad, R. \& Verheul, M. (2009): Review of flavonoids and other phenolics from fruits of different tomato (Lycopersicon esculentum mill.) cultivars. J. Sci. Food Agric., 89, 1255-1270.

Stewart, AJ., Bozonett, S., Mullen, W., Jenkins, G.I., Lean, M.E.J. \& Crozier, A. (2000): Occurrence of flavonols in tomatoes and tomato-based products. J. Agric. Food Chem., 48, 2663-2669.

Stewart, A.J., Chapman, W., Jenkins, G I., Graham, I., Martin, T. \& Crozier, A. (2001): The effect of nitrogen and phosphorus deficiency on flavonoid accumulation in plant tissues. Plant Cell Environ., 24, 1189-1197. 